\title{
REVITALISASI CERITA RAKYAT BERBASIS WAYANG KARDUS UNTUK PEMAHAMAN NILAI MORAL ANAK USIA 4-5 TAHUN DI TK 'AISYIYAH 3 SURABAYA
}

\author{
Vitis Indra Qomariyanti ${ }^{1}$, Wahono ${ }^{2}$, Tri Kuniawati ${ }^{3}$
}

\author{
Universitas Muhammadiyah Surabaya \\ Email : vitisqo@gmail.com ${ }^{1}$,wwwahono7@ gmail.com ${ }^{2}$, trikurniawati@ fkip.um- \\ surabaya.ac.id ${ }^{3}$
}

\begin{abstract}
ABSTRAK
Penerapan metode bercerita melalui media wayang kardus berbasis cerita rakyat untuk mencegah terjadinya degradasi moral pada anak usia dini, sekaligus mengenalkan nilai moral dalam cerita rakyat, penelitian ini menggunakan metode kualitatif. Analis data dilakukan dengan cara deskriptif kualitatif. Media ini merupakan teknologi pembelajaran yang diangkat dari kesenian tradisional dan telah diinovasi ke dalam dunia anak dengan bahan, bentuk karakter, warna menarik dan berbeda dari tokoh wayang sesungguhnya. Sederhananya penelitian ini akan menjawab pertanyaan berikut, bagaimana wayang kardus berbasis cerita rakyat nusantara menjadi sebuah media terhadap metode pengembangan bahan ajar nilai moral bagi anak usia dini.Konsep pembentukan kepribadian melalui nilai afektif dalam pengembangan moral, menggunakan indikator untuk menganalisis sejauh mana kemampuan anak usia dini dalam memahami nilai afektif yang terdapat dalam cerita rakyat nusantara. Wayang kardus berbasis cerita rakyat dapat mengenalkan sekaligus menanamkan nilai agama moral dalam pembelajaran di usia dini, untuk mencegah degradasi moral sejak usia dini.
\end{abstract}

Kata Kunci : Cerita Rakyat; Pendidikan Anak Usia Dini; Pendidikan Moral; Wayang Kardus.

\begin{abstract}
The application of story-telling method through puppet story-based media of folklore to prevent the occurrence of moral degradation in early childhood, as well as introducing moral values in folklore, this research using qualitative methods. The data analysis is done by qualitative descriptive method. This media is a learning technology that is lifted from traditional art and has been innovated into children world with materials, shapes of characters, interesting and different colors from the true puppet character. Simply this research will answer the following questions, how the puppet show based on the folklore of the archipelago becomes a medium against the method of developing teaching materials of moral values for early childhood. The concept of personality formation through affective values in moral development, using indicators to analyze the extent of early childhood ability in understanding the affective value contained in the folklore of the archipelago. Carton puppet based on folklore can introduce and simultaneously instill moral religion values in learning at an early age, to prevent moral degradation from an early age.
\end{abstract}

Keywords: Folklore, Early Childhood Education Programs, Moral Education, Carton Puppet.

\section{PENDAHULUAN}

Pendidikan anak usia dini merupakan upaya pendidikan untuk menstimulasi, membimbing, mengasuh, menyediakan kegiatan pembelajaran yang akan menghasilkan kemampuan dan keterampilan pada anak. Lingkungan bagi pengasuh dan pendidikan anak usia dini adalah tempat orang-orang berinteraksi untuk tujuan membentruk generasi unggul di masa mendatang. Setiap anak berhak 
untuk hidup, tumbuh, berkembang, dan beradaptasi secara wajar sesuai dengan harkat dan martabat kemanusiaan, serta mendapat perlindungan dari kekerasan dan diskriminasi (UU No.23 Tahun 2002 tentang perlindungan anak).

Karakter merupakan tonggak emas dalam setiap individu manusia dalam berperilaku di lingkungan masyarakat. Ahmar Tafsir (2003:107) Anak yang tidak dikembangkan aspek moralkeagamaanya kelak di masa dewasa akan menjadi orang yang relatif sulit untuk dididik moralitas dan keagamaan. Dari pemaparan teori tersebut, karakter adalah elemen penting dalam setiap individu. Pemahaman karakter baik sangat dianjurkan dan diajarkan kepada anak usia dini, jika tidak maka dapat berdampak buruk bagi kegagalan pembangunan karakter dan dapat menjadi ancaman besar bagi krisis karakter bangsa.

Cerita rakyat adalah salah satu metode yang dapat digunakan untuk membentuk dan membangun karakter anak. Atas dasar ini cerita rakyat dapat digunakan sebagai sarana membangun dan memberi pemahaman karakter baik bagi anak. Karena cerita rakyat kaya akan kearifan lokal serta mengandung nilai-nilai edukatif dan budi pekerti bangsa yang luhur (Subiyantoro, 2012:100). Namun banyak masalah yang menyebabkan cerita rakyat tidak dikenal oleh generasi penerusnya, menurut Ibrahim (2009:27) Menyatakan bahwa peminat sastra cerita rakyat sudah semakin sedikit karena kemajuan teknologi selalu menawarkan sumber hiburan alternatif yang menarik minat masyarakat pada umumnya. Hal tersebut berdampak pada kecintaan masyarakat terutama anakanak terhadap cerita rakyat yang ada di Indonesia.

Cara anak memahami dunia mereka semakin lama menjadi makin kompleks. Perubahan kognitif ini juga berdampak pada berubahnya pemahaman mereka dalam nilai moral. Pada umumnya kemampuan anak usia 4-6 tahun dalam aspek perkembangan nilai agama moral berkembang secara optimal. Seperti yang tercantum dalam Peraturan Menteri Pendidikan Nasional Replubik Indonesia No. 58 Tahun 2009, bidang pengembangan nilai agama moral di TK meliputi: mengenal Tuhan, meniru gerakan beribadah, mengenal perilaku baik/sopan dan buruk, membiasakan diri berperilaku baik, memahami perilaku mulia (jujur, penolong, sopan, hormat). Dalam kegiatan bersosialisasi dengan temannya anak-anak mengerti akan perbuatan baik dan buruk. Namun terkadang sering kali guru mengingatkan, menegur dan mengarahkan beberapa anak yang membangkang yang tidak berperilaku baik: (1) Kegiatan pembelajaran nilai agama moral kelompok A-2 di TK 'Aisyiyah 3 Surabaya belum berkembang secara maksimal yang sesuai dengan tingkat pencapaian perkembangan di dalam Permen Diknas No. 58 Tahun 2009. 
Perkembangan aspek nilai agama moral, khususnya dalam sikap sopan santun anak di kelompok A-2 masih kurang, belum sesuai dengan karakteristik perkembangan nilai agama moral anak usia 4-5 tahun. Adapun tujuan penelitian ini adalah Untuk mengetahui penyebab ancaman degradasi moral anak usia dini di TK 'Aisyiyah 3 Surabaya. (2) Untuk mengetahui cara revitalisasi cerita rakyat Surabaya pada pendidikan anak usia dini di TK 'Aisyiyah 3 Surabaya. (3) Untuk mengetahui media revitalisasi cerita rakyat Surabaya dalam menanamkan nilai moral anak usia dini di TK 'Aisyiyah Surabaya.

\section{METODE PENELITIAN}

Dalam penelitian ini untuk menguji data hingga baik yang digunakan adalah metode kualitatif melalui pendekatan deskriptif dalam studi kasus. Penelitian kualitatif menurut Moleong (2011:6) Penelitian yang bermaksud untuk memahami fenomena tentang apa yang dialami oleh subjek oenelitian misalnya perilaku, persepsi, motivasi, tindakan, dll., secara holistik, dan dengan cara dekskriptif dalam bentuk kata-kata dan bahasa, pada suatu konteks khusus yang alamiah dan dengan memanfaatkan berbagai metode alamiah. Hal ini selaras dengan pendapat Musfiqon (2016:70) Penelitian kualitatif merupakan penelitian yang jenis datanya nonangka. Hal ini diperkuat oleh pendapat Moleong (2011:11) data yang dikumpulkan adalah berupa kata-kata, gambar, dan bukan angka-angka. Laporan penelitian akan disajikan dengan kutipan data untuk memberi gambaran penyajian. Ditinjau dari jenis masalah yang diselidiki, teknik dan alat yang digunakan dalam meneliti, serta tempat dan waktu penelitian dilakukan, penelitian deskriptif dapat dibagi atas beberapa jenis, salah satunya adalah penelitian studi kasus. Menurut Maxfield dalam Nazir (1999:66) studi kasus atau Penelitian Kasus (Case Study), adalah penelitian tentang status subjek penelitian yang berkenan dengan suatu fase spesifik atau khas dari keseluruhan personalitas.Menurut Musfiqon dalam bukunya yang berjudul Panduan Lengkap Metodologi Penelitian Pendidikan (2016:76) beliau menyatakan bahwa dalam dunia pendidikan, penelitian studi kasus ini cukup banyak objek kajiannya, terutama masalah praktis pendidikan (penerapan metode, media pembelajaran, sumber pembelajaran, bahkan model pengelolahan pendidikan).

Penelitian ini dilakukan di TK 'Aisyiyah 3 Jalan Tambaksegaran wetan 108-110 Kecamatan Tambaksari, Kelurahan Rangkah, Surabaya. Waktu penelitian ini adalah bulan November 2017-Januari 2018. Sampel dalam Penelitian ini adalah anak A-2, terdiri dari 12 siswa laki-laki dan 12 siswa perempuan yang jumlah keseluruhannya adalah 24 siswa. Sampel dalam penelitian ini adalah kelompok A-2 yang masuk dalam 
kategori umur 4-5 tahun, dengan mengambil 7 responden. Subyek dalam penelitian ini adalah guru dan murid kelompok A-2.

Teknik pengumpulan data tidak lain dari suatu proses pengadaan data primer untuk keperluan penelitian. Menurut Nazir (1998:211) dalam bukunya yang berjudul Metode Penelitian menyatakan bahwa pengumpulan data adalah prosedur yang sistematik dan standar untuk memperoleh data yang diperlukan. Hal ini juga diperkuat oleh Sugiono (2011:224) Teknik pengumpulan data merupakan langkah yang paling strategis dalam penelitian, karena tujuan utama dari penelitian adalah mendapatkan data. Dalam penelitian kualitatif, pengumpulan data dilakukan pada natural setting (kondisi yang alamiah), sumber data primer, dan teknik pengumpulan data lebih banyak pada observasi berperan serta (participan observation), wawancara mendalam (in depth interview) dan dokumentasi (Sugiyono, 2011:225).

Tabel 1 Indikator Pencapaian

Perkembangan

\begin{tabular}{|l|l|l|}
\hline $\begin{array}{c}\text { Tingkat } \\
\text { Pencapaian } \\
\text { Perkembang } \\
\text { an }\end{array}$ & \multicolumn{1}{|c|}{ Indikator } & \multicolumn{1}{|c|}{$\begin{array}{c}\text { Butir } \\
\text { Pernyataa } \\
\text { n (Item) }\end{array}$} \\
\hline $\begin{array}{l}\text { Mampu } \\
\text { menyebutkan } \\
\text { kata-kata } \\
\text { santun, seperti } \\
\text { maaf, tolong, } \\
\text { dan lain-lain. }\end{array}$ & $\begin{array}{l}\text { 1.Mampu } \\
\text { menyebutkan } \\
\text { (mata kata sopan } \\
\text { permisi, }\end{array}$ & $\begin{array}{l}\text { Menyebutk } \\
\text { an kata } \\
\text { terimakasih). } \\
\text { sopan } \\
\text { dengan } \\
\text { inisiatif } \\
\text { sendiri. } \\
\bullet \text { Berkata }\end{array}$ \\
& & $\begin{array}{l}\text { sopan } \\
\text { dengan }\end{array}$ \\
\hline
\end{tabular}

\begin{tabular}{|c|c|c|}
\hline $\begin{array}{c}\text { Tingkat } \\
\text { Pencapaian } \\
\text { Perkembang } \\
\text { an }\end{array}$ & Indikator & $\begin{array}{c}\text { Butir } \\
\text { Pernyataa } \\
\text { n (Item) }\end{array}$ \\
\hline & & $\begin{array}{l}\text { siapapun. } \\
\text { - Menguc } \\
\text { apkan } \\
\quad \text { kata } \\
\text { terimaka } \\
\text { sih. } \\
\text { - Berdoa. } \\
\text { - Menolon } \\
\text { ng } \\
\text { seseorang } \\
\text { yang } \\
\text { memerluka } \\
\text { n bantuan. }\end{array}$ \\
\hline & \begin{tabular}{|l|} 
2. Sopan jika \\
meminta \\
bantuan kepada \\
orang lain.
\end{tabular} & \begin{tabular}{l} 
Meminta \\
bantuan \\
dengan \\
sopan, \\
tanpa \\
membenta \\
k. \\
- Meminta \\
tolong \\
dengan \\
sopan. \\
- Menguc \\
\multicolumn{2}{c}{ apkan } \\
salam. \\
- Senang \\
memban \\
tu \\
sesama.
\end{tabular} \\
\hline & 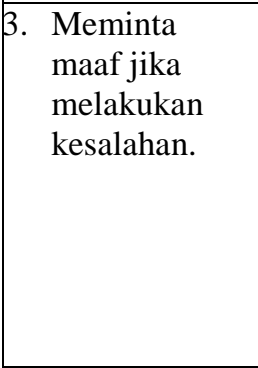 & $\begin{array}{l}\text { Meminta } \\
\text { maaf tanpa } \\
\text { disuruh } \\
\text { jika telah } \\
\text { melakukan } \\
\text { kesalahan. } \\
\text { - Meminta } \\
\text { maaf tanpa } \\
\text { disuruh. }\end{array}$ \\
\hline & $\begin{array}{l}\text { 4. Mengucapkan } \\
\text { kata permisi jika } \\
\text { hendak } \\
\text { melewati orang } \\
\text { yang sedang } \\
\text { duduk. }\end{array}$ & $\begin{array}{l}\text { Mengucap } \\
\text { kata } \\
\text { permisi } \\
\text { jika ingin } \\
\text { melewati } \\
\text { orang yang } \\
\text { sedang } \\
\text { duduk di } \\
\text { dekatnya. } \\
\text { - Menguc } \\
\text { apkan kata } \\
\text { permisi } \\
\end{array}$ \\
\hline
\end{tabular}




\begin{tabular}{|c|c|c|}
\hline \multirow[t]{3}{*}{$\begin{array}{c}\text { Tingkat } \\
\text { Pencapaian } \\
\text { Perkembang } \\
\text { an }\end{array}$} & Indikator & $\begin{array}{c}\text { Butir } \\
\text { Pernyataa } \\
\text { n (Item) }\end{array}$ \\
\hline & & $\begin{array}{l}\text { jika } \\
\text { hendak } \\
\text { melewati } \\
\text { orang yang } \\
\text { sedang } \\
\text { duduk di } \\
\text { dekatnya. }\end{array}$ \\
\hline & $\begin{array}{l}\text { 5. Mengucapkan } \\
\text { kata terimakasih } \\
\text { jika diberi oleh } \\
\text { orang lain. }\end{array}$ & $\begin{array}{l}\text { Berterimak } \\
\text { asih } \\
\text { kepada } \\
\text { seseorang } \\
\text { yang telah } \\
\text { memberiny } \\
\text { a sesuatu. } \\
\text { - Menguc } \\
\text { apkan kata } \\
\text { terimakasi } \\
\text { h jika } \\
\text { diberi } \\
\text { sesuatu } \\
\text { oleh orang } \\
\text { lain. }\end{array}$ \\
\hline
\end{tabular}

\section{Analis data adalah proses} mencari danmenyusun secara sistematis data yang diperoleh dari hasil wawancara, catatan lapangan, dan bahan-bahan lain, sehingga dapat mudah dipahami dan temuannya dapat diinformasikan kepada orang lain (Bodgan dalam Sugiyono, 2011:144). Menurut Bodgan dan Biklen dalam Moleong, 2011:248, Analis data kualitatif adalah upaya yang dilakukan dengan jalan bekerja dengan data, mengorganisasikan data, memilah-milahnya menjadi satuan yang dapat dikelola, mensistensiskannya, mencari dan menemukan pola, menemukan apa yang penting dan apa yang dipelajari, dan memutuskan apa yang dapat diceritakan kepada orang lain. Dalam penelitian kualitatif analis data dilakukan pada saat pengumpulan data berlangsung, dan setelah selesai pengumpulan data dalam periode tertentu (Sugiyono, 2011: 246). Miles dan Huberman dalam Sugiyono (2011:246), mengemukakan bahwa aktivitas dalam analisis data kualitatif dilakukan secara interaktif dan berlangsung secara terus menerus sampai tuntas, hingga datanya sudah jenuh.

Menurut Miles dan Huberman dalam Sugiyono (2011:246) Aktivitas dalam analis data, yaitu data reduction, data display, dan conclustion drawing/verification. (1) Data Reduction (Reduksi Data) Mereduksi data berarti merangkum, memilih hal-hal yang pokok, memfokuskan pada hal-hal yang penting, dicari tema dan polanya. Dengan demikian data yang telah direduksi akan memberikan gambaran yang lebih jelas dan mempermuda peneliti untuk melakukan pengumpulan data selanjutnya, dan mencarinya bila diperlukan; (2) Data Display (Penyajian Data) Setelah data direduksi maka langkah selanjutnya adalah mendisplaykan data. Dalam penelitian kualitatif, penyajian data dapat dilakukan dalam bentuk uraian singkat, bagan, hubungan antar kategori, flowchart dan sejenisnya, yang paling sering digunakan untuk menyajikan data dalam penelitian kualitatif adalah dengan teks yang bersifat naratif; (3) Conclusion Drawing/Verification Langkah 
berikutnya adalah penarikan

Kesimpulan awal yang dikemukakan masih bersifat sementara, dan akan berubah bila tidak ditemukan buktibukti yang kuat yang mendukung pada tahap pengumpulan data berikutnya. Tetapi apabila kesimpulan yang dikemukakan pada tahap awal, didukung oleh buktibukti yang valid dan konsisten saat peneliti kembali ke lapangan mengumpulkan data, maka kesimpulan yang dikemukakan merupakan kesimpulan kredibel.

\section{PEMBAHASAN}

Kemerosotan moral anak usia dini adalah sebuah ancaman yang sangat dikhawatirkan keberadaannya oleh semua lapisan masyarakat, terutama bagi orang tua maupun guru. Menurut Hurlock dalam bukunya Child Development (1978:74) Perilaku tidak bermoral adalah perilaku yang tidak sesuai dengan harapan sosial atau kurang adanya perasaan wajib menyesuaikan diri, sedangkan perilaku amoral adalah perilaku yang disebabkan ketidakacuhan terhadap harapan kelompok sosial dari pada pelanggaran sengaja terhadap standar kelompok.

Hasil pengamatan yang diperoleh selama penelitian di TK 'Aisyiyah 3 Surabaya, penyebab ancaman degradasi moral anak usia dini disebabkan oleh aktivitas anak yang sering menggunakan 'gadget' dalam menghabiskan waktu senggangnya, sehingga menimbulkan kurangnya rasa bersosialisasi anak dalam bergaul maupun kurang pemahaman para siswa terhadap nilai moral dalam bersikap. Menurut hasil wawancara dengan Ibu Lidya Savitri selaku wali kelas kelompok A-2 (jum'at 09 Januari 2018) Para siswa yang menjadi responden adalah siswa yang sulit untuk diatur, tidak sopan dalam berucap, bersikap, bahkan dalam berperilaku. Nilai moral yang terdapat dalam ketujuh responden memang benar-benar terkesan kurang baik. Mereka terkesan tidak sopan dan kurang memiliki karakter baik, seperti berkata kasar, berkata dengan nada keras, tidak membalas maupun mengucap salam, lari tanpa mengucapkan kata sopan seperti kata permisi jika hendak melewati orang lain yang berada di dekatnya, tidak berterimakasih jika diberi sesuatu maupun mendapat bantuan dari orang lain. Fakta ini juga dikuatkan oleh pendapat Helden dan Richards dalam Sjarkawi (2014:28) Pengertian moral sebagai suatu kepekaan dalam pikiran, perasaan dan tindakan dibandingkan dengan tindakan lain yang hanya berupa kepekaan terhadap prinsip dan aturan. Moral memiliki arti perilaku yang sesuai dengan kode moral kelompok sosial (Hurlock, 1978:74). Oleh karena itu moral yang berkualitas perlu dibentuk dan dibina sejak usia dini, karena pada usia dini seseorang individu sedang mengalami masa emas yang hanya terjadi sekali seumur hidup. 
Anak usia dini adalah individu yang sedang mengalami proses pertumbuhan dan perkembangan yang sangat pesat, bahkan dikatakan sebagai lompatan perkembangan (Mulyasa, 2012:16). Maka dari itu jika ingin membentuk generasi cerdas, berbudi luhur, sehat jasmani maupun rohaninya dapat dibentuk sejak usia dini. Individu yang sedang mengalami masa emas bukanlah miniatur dari orang dewasa, mereka tidak dapat dituntut untuk tunduk pada hukum dan kebiasaan tuntutan yang diberikan oleh orang dewasa. Namun untuk melatih pemahaman anak usia dini terhadap nilai moral yang ada, pendidik maupun orang tua harus mengenalkan mereka pada karakteristik moral baik dalam menanamkan nilai moral kepada anak maka dapat ditanamkan rasa malu dan rasa bersalah.

Cerita rakyat adalah salah satu metode yang dapat digunakan untuk membentuk dan membangun karakter anak (Subiyantoro, 2012:100). Namun maraknya penggunaan gadget dan kurangnya bersosialisasi anak dengan orang lain, dapat juga menimbulkan kurangnya pengetahuan anak terhadap cerita rakyat Surabaya. Menurut Ibrahim (2009:27) Peminat sastra cerita rakyat sudah semakin sedikit karena kemajuan teknologi selalu menawarkan sumber hiburan alternatif yang menarik minat masyarakat terutama kepada anakanak usia dini, hal tersebut berdampak pada kurang kecintaan anak-anak terhadap cerita rakyat.
Cara merevitalisasi cerita rakyat Surabaya pada pendidikan anak usia dini di TK 'Aisyiyah 3 Surabaya adalah dengan menggunakan bahasa anak. Menurut hasil wawancara dengan Ibu Lidya Savitri selaku wali kelas kelompok A-2, dengan menggunakan bahasa anak dalam kegiatan bercerita dapat menjadikan suasana komunikasi lebih aktif, interaktif dan efisien karena anak-anak lebih muda memahami jalannya cerita yang disuguhkan (Wawancara, 19 Januari 2018). Seperti halnya Ibu Lidia Savitri memainkan wayang kardus yang diawali dengan kegiatan menyapa anak-anak, memainkan gestur wajah sebagai pelengkap kegiatan berceritanya, mengajak anak untuk memegang dan memainkan wayang kardus yang dibawanya (Observasi, 29 Januari 2018). Namun terkadang ada beberapa anak yang terilihat asik mengobrol, bermain sendiri, bahkan menganggu temannya yang sedang menyimak cerita, Ibu Lidya tidak memotong jalannya cerita namun, beliau menggunakan gestur wajah yang mengisyaratkan anak untuk segera tenang dan kembali mengikuti kegiatan bercerita yang sedang berlangsung (Observasi, 30 Januari 2018).

Perkembangan anak tidak akan terlepas dari konteks sosial budaya yang mengelilinginya. Untuk mewujudkan jalannya proses revitalisasi cerita rakyat Surabaya untuk disuguhkan kepada anak, maka di TK 'Aisyiyah 3 Surabaya 
menggunakan media wayang kardus yang berbahan aman. Wayang kardus ini dibuat dari bahan utama kardus yang dicat dengan cat minyak yang diberi pernak-pernik untuk menunjang karakter yang dibawanya, adapun pegangan yang digunakan untuk memainkannya adalah dengan menggunakan stik bambu yang telah dihaluskan serta dililit oleh isolasi kertas, sehingga anak dapat memainkannya secara aman dan menyenangkan.

Pemilihan cerita rakyat yang digunakan untuk penanaman nilai moral kepada nak usia dini menggunakan cerita rakyat yang menyuguhkan amanat moral baik dan sesuai dengan kurikulum yang sudah disusun oleh TK 'Aisyiyah 3 Surabaya. Amanat cerita rakyat yang telah dipilih mengandung pesan moral: anak terbiasa dalam menghormati teman, anak terbiasa mengucapkan salam ketika masuk maupun keluar ruangan atau berpamitan, anak terbiasa tertib dan menghormati teman, anak terbiasa menghormati teman maupun guru.

Tabel 2 Hasil Rekapitulasi

\begin{tabular}{|c|c|c|c|c|c|c|c|c|c|c|}
\hline \multirow{3}{*}{$\mathrm{Sa}$} & \multirow{3}{*}{ Requades } & \multicolumn{9}{|c|}{ Pandzaua Solap Braut } \\
\hline & & 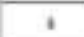 & & 5 & & 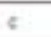 & 4 & & 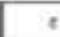 & \\
\hline & & 432 & +3 & 921 & $1+3$ & 321 & +3 & 21 & 43 & $2 \mid 1$ \\
\hline I & 2mpada 1 & 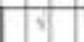 & $\sqrt{7}$ & & 7 & & $\sqrt{x}$ & & 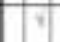 & \\
\hline 2 & Respode? & प1 & & & & st & & $\sqrt{ }$ & & \\
\hline 7 & Pnowade? & ग & 7 & & ง & S & T & & & \\
\hline$\frac{1}{4}$ & Resudat & & & & v & o & V & & 4 & \\
\hline 5 & Inpeade 5 & 1 & 5 & & & & & & & 7 \\
\hline $\bar{b}$ & Inppade 6 & 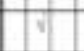 & & & & 11 & r & v & & \\
\hline 2 & Imponde? & 14 & vi & & 1. & & 1. & & & \\
\hline
\end{tabular}

Keterangan :

a : selalu berdoa dengan tertib ketika kegiatan berdoa berlangsung b : mengucapkan salam ketika

hendak masuk kelas

$\mathrm{c}$ : meminta maaf ketika ia melakukan sebuah kesalahan kepada orang lain

$\mathrm{d}$ : selalu berterimakasih jika ia diberi sesuatu oleh orang lain e : selalu meminta tolong dengan sopan ketika ia memerlukan bantuan

\begin{tabular}{|c|c|c|c|c|c|c|c|c|c|c|c|c|c|c|}
\hline \multirow{3}{*}{ No. } & \multirow{3}{*}{ Rewanden } & \multicolumn{13}{|c|}{ Peashumaz Sikap llarmat } \\
\hline & & \multicolumn{2}{|r|}{ I } & \multicolumn{3}{|c|}{1} & \multicolumn{2}{|r|}{ h } & \multicolumn{3}{|c|}{1} & \multicolumn{3}{|c|}{ i } \\
\hline & & $4 \sqrt{3}$ & 12 & 4 & [3]: & 1 & 43 & 2 & 4 & $3: 2$ & 1 & 43 & & 1 \\
\hline 1 & Regcoden ! & จ & & & I & & จ & & & ( ) & & v & & \\
\hline 2 & Repender 2 & & & 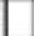 & & 3 & & & $\mathrm{I}$ & P & & ( & & s \\
\hline 3 & Repende? & v & ti & $\mathrm{N}$ & & & v & & & i & & v & & \\
\hline 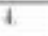 & Repsonden 4 & 4 & it & & & 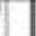 & จ & If & & 1 & & จ & & \\
\hline 2 & Repsides ? & & & & & v & v & & & & y & & v & \\
\hline 6 & Repseden 6 & & ज小 & & & T & จ & & & T & & & 1. & 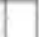 \\
\hline I & Reswates? & vi & & & & v & 7 & if & & ง & & गे & & \\
\hline
\end{tabular}

\section{Keterangan :}

$\mathrm{f}$ : senang membantu temannya maupun orang lain jika dimintai bantuan

$\mathrm{g}$ : selalu mengucapkan kata permisi jika hendak melewati orang yang sedang duduk di dekatnya $\mathrm{h}$ : berinisiatif untuk menolong kesulitan yang dialami oleh temannya i : selalu berkata sopan dengan orang lain maupun temannya $\mathrm{j}$ : perkembangan anak setelah mendengar cerita rakyat Sawunggaling dan Asal Mula Nama Surabaya

Berdasarkan hasil penelitian dari indikator sikap hormat dalam pengembangan aspek nilai moral banyak anak yang memperoleh bintang 3, kemudian disusul bintang 2 dengan sedikit selisih dari bintang 4 dan bintang 1. Untuk frekuensi bintang 4 ada 15 anak yang mencapainya. Pada pedoman penilaian TK (Kemendiknas, 2013:11) bintang 3 didefinisikan 
bahwa anak sudah berkembang sesuai harapan. Jadi pada pembiasaan sikap hormat kepada guru di TK 'Aisyiyah 3 Surabaya anak sudah nampak perkembangannya karena dilihat dari hasil yang diperoleh dengan banyaknya anak yang memperoleh bintang 3 dan yang paling rendah adalah 14 anak yang masih belum berkembang dengan hasil memperoleh bintang 1. Berdasarkan analis dari peneliti bahwa pendidikan dan penanaman sikap hormat dalam aspek perkembangan moral, bahwa anak-anak masih memerlukan waktu yang lebih lama untuk melakukan pembiasaan dengan arahan dan bimbingan guru. Dalam waktu kurang lebih tujuh bulan anak kelompok A baru masuk TK 'Aisyiyah 3, pendidikan moral baik pada diri anak masih dalam tahap berkembang sesuai harapan.

\section{KESIMPULAN}

Penyebab ancaman degradasi moral anak usia dini di TK 'Aisyiyah 3 Surabaya diketahui bahwa anak sering menggunakan 'gadget' secara berlebih dalam sehari sehingga menimbulkan kurangnya rasa bersosialisasi anak dalam bergaul dengan temannya, guru maupun orang lain. Selain itu penyebab ancaman degradasi moral di TK 'Aisyiyah 3 Surabaya para siswa kurang paham terhadap nilai moral dalam bersikap. Adapun dampak dari kedua penyebab tersebut adalah karakter anak menjadi kurang baik, seperti berkata kasar, berkata dengan nada keras, tidak membalas maupun mengucap salam, lari tanpa mengucapkan kata sopan jika hendak melewati orang lain yang berada di dekatnya, tidak berterimakasih jika diberi sesuatu maupun mendapat bantuan dari orang lain.

Berdasarkan hasil penelitian yang dilakukan di TK 'Aisyiyah 3 Surabaya tentang penanaman nilai moral anak usia dini melalui metode bercerita berbasis wayang kardus terhadap kelompok A-2, dapat dilakukan dengan menggunakan penerapan pembiasaan, penguatan serta keteladanan yang baik. Sebab moral yang berkualitas perlu dibentuk dan dibina sejak usia dini, karena dalam usia dini seseorang individu sedang mengalami masa emas yang hanya terjadi sekali seumur hidup.

\section{Daftar Pustaka}

Ahimsa-Putra, dan Heddy, Shri. 2001. Struktualisme Levi Strauss Mitos dan Karya Sastra. Yogyakarta: Galang Printika.

Aisyah, Siti (2014) Perkembangan dan Konsep Dasar Pengembangan Anak Usia Dini. Jakarta: Universitas Terbuka.

Arief S. Sadiman, dkk., Media Pendidikan, (Jakarta: Penerbit Rajawali Pers, 2010), hlm. 6.

Azhar Arsyad, Media Pembelajaran, (Jakarta: Penerbit Rajawali Pers, 2011), hlm, 3.

Danandjaja, James. 2007. Folklor Indonesia, Ilmu Gosip, 
Dongeng, dan lain-lain. Jakarta:Pustaka Utama Grafiti.

Hurlock, Elizabeth (1978), Child Development, sixth Edition. McGraw-Hill.

Ibrahim, Maniyamin. 2009. Konteks Sastra Melayu \& Budaya Melayu. Malaysia: Karisma Publications Sdn. Bhd.

Indri, 2010. Sawunggaling Sebuah Legenda Surabaya. Grafika Indah Jakarta

Santrock, 2002. Perkembangan Anak. Erlangga Jakarta.

Suyadi, 2010. Psikologi Belajar PAUD. PEDAGOGIA

Megawangi, Ratna (2004), Pendidikan Karakter, Solusi Yang Tepat untuk Membangun Bangsa. Jakarta:

Migas dan Star $\begin{aligned} & \text { Energy, } \\ & \text { Heritage }\end{aligned}$
Indonesia
Foundation.

Sutarjo, 2013. Pembelajaran Nilai Karakter Konstruktivisme dan VCT sebagai Inovasi Pendekatan Pembelajaran Afektif. Depok Raja Grafindo Persada.

Sjarkawi, 2014. Pembentukan Kepribadian Anak Peran Moral, Intelektual, Emosional dan Sosial Sebagai Wujud Integritas Mambangun Jati Diri. Jakarta PT Bumi Aksara.

Windiyarti, Dara (2010) Legenda Panji Laras Panji Liris. Prosiding Seminar Internasional Austronesian Languages and Literatures, Udayana. 778-782. 